\title{
Review
}

\section{Displacing Caravaggio: art, media, and humanitarian visual culture}

\author{
Francesco Zucconi \\ Palgrave Macmillan, London, 2018, xi + 244 pp., ISBN 978-3-319-93377-1
}

Contemporary Political Theory (2021) 20, S135-S139. https://doi.org/10.1057/s41296020-00424-2; published online 13 July 2020

In Displacing Caravaggio: Art, Media, and Humanitarian Visual Culture, Francesco Zucconi examines the relationship between the works of art of the Italian baroque painter Michelangelo Merisi da Caravaggio, infused as they are in religious iconography, and contemporary humanitarian intervention in the context of the European migration 'crisis'. In doing so, Zucconi accomplishes two things. On the one hand, he problematises the relationship between humanitarian communication and art history, that is, the ennoblement of humanitarianism through art, and the return to relevance of the art of the old masters through contemporary humanitarianism (p. 67). On the other hand, the book's narrative is centred on addressing the political question of what kinds of interventions and representations can point to social change as an imperative to act on behalf of those migrants who suffer and who are the subjects of humanitarian intervention and art exhibitions.

In the first chapter, Zucconi introduces this argument and the problematic that underlies the book, starting from the normative question of what art is for. This question forms the broader context of the book, where Zucconi questions whether we need art to serve a purpose and what it is that we, as viewers, expect from it. Ultimately, if art is framed in such a way as to serve a purpose, in this case a humanitarian one, does it matter what the artists themselves stood for? By placing Caravaggio's art in the context of the migration 'crisis' and drawing on the meaning of his paintings to invoke a sense of common humanity as it is conceived by scholars of media ethics, Zucconi explores how Caravaggio's art itself works to contribute to this connection.

The second chapter contains the theoretical overview of the book and, in line with studies in media ethics, introduces visual culture in the context of humanitarian communication as the capacity to convey values and teach behaviours (p. 29). Zucconi frames this combination of visual culture studies and humanitarian communication applied to the study of works of art as serving to emphasise suffering and the human condition of need as 'humanitarian archaeology'. The

(c) 2020 Springer Nature Limited. 1470-8914 Contemporary Political Theory Vol. 20, S3, S135-S139 
central relationship between visual culture and the humanitarian and human rights agenda are historicised as parallel processes, whereby the Renaissance brought a view of icons and religious iconography as active in their capacity to model values and behaviours, while humanitarian communication is similarly seen as serving as a moral education to audiences towards victims. It is mercy that comes about as a central feeling aroused in this relationship of seeing suffering, and Zucconi identifies the inability of this kind of relationship between the sufferer and the viewer to fully evoke the political dimension of viewing others' suffering. In other words, the psychological, historical, and social circumstances of those who receive mercy are overlooked in favour of a relationship of subordination and dependence of those who receive mercy upon those who are in a position to give it, collapsing all sufferers in a role of a needy mass devoid of particularity and identity.

Zucconi's critique of humanitarian and human rights advocacy reflects studies in the fields of media, gender, and communication (see, for example, Chouliaraki, 2013; Chouliaraki and Stolic, 2019; Moyn, 2018; Silverstone, 2007; Ticktin, 2014, 2016) which show that both humanitarianism and human rights causes often foreclose the possibility of politicising these causes in their aims to generalise suffering and convey a common humanity. Put differently, these critics propose that representations of suffering too often slip into generalisable and essentialist discourses that rely on conveying immediate humanitarian need (Ticktin, 2011) or the floor of human rights protection (Moyn, 2018). In so doing, they obfuscate the social, cultural, economic, and intersectional conditions of oppression and disadvantage that render people vulnerable and cause human suffering. Zucconi makes use of some of these arguments, but they are never fully utilised in the service of unpacking how exactly this process of depoliticisation operates in the relationship between the art of Caravaggio and the migration crisis which serves as the book's case study.

In the subsequent three chapters, Zucconi turns to an exploration of the notion of displacement, a central concept within the book, through examples of contemporary humanitarian communication in light of various themes that appear in the works of Caravaggio and the different uses of the artist's work in the humanitarian context. In chapter three, the analysis of some of Caravaggio's paintings serves to probe questions of race and Orientalism and focuses on the relationship between the content of the paintings themselves and the interpretations of their meanings and the language used to describe them. Zucconi engages the discursive construction of meaning about the paintings and their relationship to various historical moments within which the paintings are analysed and rendered meaningful. In particular, Zucconi compares a 1960s analysis of Caravaggio's painting, which relies on Orientalist tropes and racialised interpretations of its non-white subjects, to humanitarian photography of the twenty-first century, in order to reflect on the hierarchisation of racialised bodies and these images' (in)ability to bring about social and political recognition. Contemporary visual strategies of humanitarian photography that construct racialised and hierarchical notions of humanity, Zucconi argues,

S136 단 2020 Springer Nature Limited. 1470-8914 Contemporary Political Theory Vol. 20, S3, S135-S139 
are interrupted in Caravaggio's painting, where relationships of subordination are denied and bodies are presented as equal in their humanity. This is, according to the author, one of the lessons to learn from Caravaggio's paintings in the context of contemporary humanitarian communication.

Chapter four explores the notion of pathos in humanitarian photography, which is constructed to inspire feelings of charitable participation but precludes reflections on the historical and socio-political circumstances that lead to violence and suffering. The chapter explores the framing of photographs of suffering via captions that refer to Christian values and religious iconography in order to orient pathos in a particular direction. The gendered representations of women as sacred at the same time as the political force of their representation is lost, Zucconi argues, creates a biopolitical space where the sacred life of a woman is elevated through her insertion into standard religious iconography. This kind of framing creates a precarious space where her suffering loses its political valence. Instead, Zucconi proposes that we should rely on representations of mundane life rather than exceptional suffering and oppression in order to foster recognition and preserve the political nature of suffering.

The topic of chapter five is humanitarian media campaigns, particularly a campaign that relies on virtual reality (VR) technology as an awareness-raising tool. Zucconi compares this to lantern slide lectures that were used for humanitarian purposes in the nineteenth and twentieth centuries as well as to candlelit paintings that were used to show Caravaggio's works in Europe. Zucconi argues that these techniques were used to reduce the distance between viewers and sufferers by staging humanitarian imagery. However, drawing on Chouliaraki's (2013) notion of ironic spectatorship and post-humanitarian communication, Zucconi shows that the VR campaigns are ultimately examples of self-oriented moral engagement. He proposes that Caravaggio's self-portraits illustrate the responsibility to witness the violence in the world and the feelings of pity that arise from viewing suffering, and does this in order to highlight the importance of focusing on the mediality of distance as a space for aesthetic, ethical, and political experimentation, which opens the possibility to pose questions of power that underlie humanitarian practice (p. 181).

Chapter six contains an analysis of the book's foundational case study, namely a 2016 exhibition on the island of Lampedusa called Towards the Museum of Trust and Dialogue for the Mediterranean, where Caravaggio's painting Sleeping Child was displayed. Zucconi argues that the meanings of displacement and victimhood are only hinted at by situating the exhibition on Lampedusa, with its history of disaster and shipwreck, in juxtaposition with the meaning of Caravaggio's painting. Any explicit contextualisation or exploration of ethical and political issues is left out, and the exhibition space as well as the painting are left to imbue the exhibition with humanitarian imperatives on their own. Ultimately, Zucconi suggests, the transfer of Caravaggio's painting to the island and its presentation alongside contemporary photographs of children caught in the migration 'crisis' is an invitation to reflect on

(c) 2020 Springer Nature Limited. 1470-8914 Contemporary Political Theory Vol. 20, S3, S135-S139 S137 
the power of the image and its silences (p. 189) through the exposure of suffering bodies and the potential of this exposure to evoke recognition and politicise the plight of migrants and refugees. Although this concluding chapter offers an intricate and detailed analysis that demonstrates how opening up meanings can imbue visual culture with political potential, it does not explore how this space can be mobilised politically. It also misses the opportunity to push the argument forward by reflecting on the implications of exposing injury in public and the potential toll of such exposure.

The final chapter offers a brief conclusion in which the author reflects on the value of analysing visual configurations of suffering and the transformation of meaning through a consideration of Caravaggio's paintings in a contemporary humanitarian context. Ultimately Zucconi remains sceptical about the true potential of such configurations to mobilise the political and social agency of humanitarian intervention. The chapter would have benefited from a more explicit and substantial reflection on issues of race, bordering, and testimony, which are explored in previous chapters, as a way to challenge and interrupt the dominant frameworks of humanitarian communication. Nonetheless, this book presents a useful and compelling analysis of how art history can be mobilised alongside contemporary visual culture in the service of humanitarian communication and sheds light on the potentials and challenges of drawing on the historical legacy of classical painting.

\section{References}

Chouliaraki, L. (2013). The ironic spectator: Solidarity in the age of post-humanitarianism. Cambridge, Malden, MA: Polity Press.

Chouliaraki, L., \& Stolic, T. (2019). Photojournalism as political encounter: Western news photography in the 2015 migration ?crisis'. Visual Communication, 18, 311 ?331.

Moyn, S. (2018). Not enough: Human rights in an unequal world. Cambridge, Massachusetts: The Belknap Press of Harvard University Press.

Silverstone, R. (2007). Media and morality: On the rise of the mediapolis. Cambridge: Polity.

Ticktin, M. (2011). The gendered human of humanitarianism: Medicalising and politicising sexual violence. Gender \& History, 23, 250?265.

Ticktin, M. (2014). Transnational humanitarianism. Annual Review of Anthropology, 43, 273 ?289.

Ticktin, M. (2016). Thinking beyond humanitarian borders. Social Research, 83, 255 ?271.

Zucconi, F. (2018). Displacing Caravaggio: art, media, and humanitarian visual culture. (Z. Hanafi, Trans.). Cham: Palgrave Macmillan.

Publisher's Note Springer Nature remains neutral with regard to jurisdictional claims in published maps and institutional affiliations. 
Tijana Stolic

London School of Economics and Political Science, London WC2A 2AE, UK

t.stolic@1se.ac.uk 